\title{
Fecundity, histomorphology of the ovary and size at first maturity of Neolissochilus hexagonolepis (McClelland) in Tamor River, Nepal
}

\author{
Suren Subba \\ Central Department of Zoology, Tribhuvan University, Nepal \\ Vinod Kumar Mahaseth \\ Department of Zoology, M. M. Adarsh Multiple Campus, Tribhuvan University, Nepal \\ Bharat Raj Subba \\ Department of Zoology, Post Graduate Campus, Tribhuvan University, Nepal \\ Shyam Narayan Labh* \\ Department of Zoology, Amrit Campus, Tribhuvan University, Nepal \\ ${ }^{*}$ Corresponding author. E. mail: snlabh@gmail.com
}

\section{How to Cite}

Subba, S. et al. (2020). Fecundity, histomorphology of the ovary and size at first maturity of Neolissochilus hexagonolepis (McClelland) in Tamor River, Nepal. Journal of Applied and Natural Science, 12(3): 401 - 410. https://doi.org/10.31018/ jans.v12i3.2338

\begin{abstract}
Neolissochilus hexagonolepis (McClelland, 1839) is one among the notable species in snow-fed torrential rivers of Nepal. The present study attempts to investigate some reproductive traits of $N$. hexagonolepis, including the length at first maturity, fecundity and its relationships with biometric variables like lengths (TL, SL, and FL) and weights (TW and OW) of the fish in the midreaches of Tamor River, Nepal. A total of 109 fish samples were collected from the river. For each individual, total length (TL), standard length (SL) and fork length (FL) were measured in a fully stretched condition to the nearest $1 \mathrm{~mm}$ using a measuring tape and graduated ruler, while total weight (TW) and ovary weight (OW) was measured using a digital balance with the precision of $0.01 \mathrm{~g}$. The mean absolute fecundity $(\mathrm{F})$ was $8356.44 \pm 4612.59$ and ranged from 2398.6 to 20160 . SL was more significantly correlated with absolute fecundity $\left(R^{2}=0.59 ; p<0.001\right)$ than other body metrics. The results showed that female individuals of N. hexagonolepis attained the first sexual maturity at TL $32.9 \mathrm{~cm}$. N. hexagonolepis exhibited a protracted breeding period with its ovaries passing through six different stages of maturation. The finding of the present study may serve as a protocol for fishery biologists and managers to promulgate adequate regulations for continual fishery management in the River Tamor, Nepal.
\end{abstract}

Keywords: Absolute fecundity, Maturation cycle, Reproductive traits, Size at first sexual maturity, Total length

\section{INTRODUCTION}

The term 'fecundity' denotes the total number of eggs present in the ovaries of a fish, which are likely to be laid during the next spawning season (Bagenal, 1957). The knowledge of fecundity finds a vast application in stock size assessment, stock discrimination (Holden and Raitt, 1974), and rational utilization of stock (Morales, 1991). The assessment of fecundity is useful in evaluating the variations in the fish population, commercial potentialities of its stock, life history, and in the proper management of fishery (Marimuthu et al., 2009). Fecundity and its relation with different body parameters of female fish make it possible to estimate the potential of egg output (Chondar, 1977), and its relation with other morphological characters like size, age and weight have often been used to provide a reliable index of density-dependent factors affecting the size of a population (Ulfat et al., 2014).

Biologists have been investigating fish gonads intending to identify annual reproductive cycles, length of breeding seasons, and to determine the onset of reproductive maturity and spawning rhythms (Parenti and Grier, 2004). Investigation of the histomorphology and cycle of maturation of gonads is a breakthrough in discerning the reproductive biology of fishes.

Neolissochilus hexagonolepis (McClelland, 1839) is commonly known as Copper Mahseer. It is a beautiful shiny game fish with an elongated body and a rounded abdomen. $N$. hexagonolepis is one among the notable species in snow-fed torrential rivers of Nepal. Regrettably, its population is in sharp decline due to the loss of its habitat and over-exploitation.

Tamor River serves as a typical home as well as the 
breeding ground for many hill-stream fishes, including $N$. hexagonolepis (Shrestha, 2008; Shrestha et al., 2009), but has been overlooked for unknown reasons. Currently, $N$. hexagonolepis has the conservation status of 'Near Threatened (NT)' according to the Redlist Assessment of IUCN (2018). Therefore, an essential conservational initiative is needed for this species. Unambiguous knowledge of reproductive biology is needed to proceed with any conservational efforts. Unfortunately, there is a lack of such knowledge concerning N. hexagonolepis. Recently, Jyrwa and Bhuyan (2017) have attempted to investigate the reproductive traits of $N$. hexagonolepis in Meghalaya India. But, there is no previous literature from Tamor River. In this backdrop, an attempt has been made to investigate some reproductive traits of $N$. hexagonolepis, including the length at first maturity, fecundity and its relationships with biometric variables like lengths (Total Length, Standard Length, and Forkal Length) and weights (Total weight and Gonad weight) of the fish in Tamor River.

\section{MATERIALS AND METHODS}

Ethical statement: The authors declare that there is no conflict of interest for the publication of this manuscript.

Sampling site: The study area which stretched for more than $12 \mathrm{~km}$ ( $A$ to $B$ ), lies between latitude and

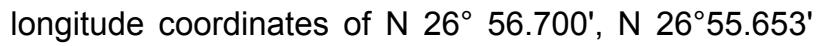
and $\mathrm{E} 087^{\circ} 23.097^{\prime}$, E $087^{\circ} 17.653^{\prime}$, respectively (Fig. 1).

Sampling and laboratory analysis: The study was conducted in the year 2019, and fish specimens gathered every month round the year. During the course, a total of 109 fish samples were procured from the river. The samples were collected with the help of local fishermen, using hooks, cast nets, and gill nets of different mesh sizes and locally constructed traps. Captured fish samples were immediately transported to the laboratory for further examination. Total Length (TL) was measured from the tip of snout to the distal tip of the longest caudal-fin ray, Standard Length (SL) from the tip of snout to the beginning of the tail fin and fork length ( $F L)$ measured from the tip of snout to the tip of the median caudal-fin ray. All these lengths were measured in a fully stretched condition to the nearest $1 \mathrm{~mm}$ using a measuring tape and graduated ruler. The total weight (TW) of each sample (including gut and gonad) was measured after removing moisture from the body with paper towels and cloth. The whole ovary was removed from the body after dissection, and ovary weight (OW) was measured. The weights (TW and OW) were measured using a digital balance with a precision of $0.01 \mathrm{~g}$.

Macroscopical staging of ovaries was validated by histology. And for this, histological slides of ovaries were prepared by fixing the smaller pieces of the gonad in freshly prepared Bouin's fluid. They were then embedded in paraffin wax and sectioned at $6 \mu$ with the help of a rotary microtome machine (Yorco YSI 115), dewaxed in xylene, hydrated and dehydrated in alcohol series. The histological sections were stained with hematoxylin, followed by eosin counterstain.

Maturity stages of ovaries of the fish were determined according to a maturity scale modified after BrownPeterson et al. (2011). The frequency of a specific stage of the gonad, based on its gross morphological and histological features was calculated and expressed as a percentage every month.

Estimation of fecundity: The gravimetric method, among many approaches endorsed for fecundity estimation of fish, is the most common and is based on the relation between ovary weight and oocyte density in the ovary. Prior to all, the homogeneity of oocyte distribution was investigated to make sure that the sub -sample to be analyzed represented the entire ovary of the fish (Murua et al., 2003). As a rule-of-thumb, a sufficient number of sub-samples is said to be reached when the coefficient of variation (cv) among the estimated number of eggs per unit weight of sub-sample is less than 5\% (Kjesbu and Kryvi, 1989). By taking three sub-samples, the gravimetric method provided sufficient precision of the estimates with the mean coefficient of variation (cv) less than $5 \%$. So, in the present study, the gravimetric method was adopted for the estimation of the fecundity of $N$. hexagonolepis.

After determining the weight of the ovary, three subsamples of $1 \mathrm{~g}$ each were obtained from the anterior, middle, and posterior parts of the ovary. The eggs were then washed with distilled water and gently teased with needle and forceps until they became disentangled from ovarian tissues. The eggs were then spread over blotting paper to remove excess moisture, and the clamped eggs were gently separated. The eggs were then air-dried. The total number of eggs in each ovary sub-sample was proportionally estimated using the equation, $F_{1}=$ (gonad weight $X$ number of eggs in the sub-sample) / sub-sample weight (Yelden and Avsar, 2000). Finally, by taking the mean of three sub-sample fecundities $\left(F_{1}, F_{2}\right.$, and $\left.F_{3}\right)$, the absolute fecundity $(F)$ was estimated as $F=\left(F_{1}+F_{2}+F_{3}\right) / 3$ (Hossain et al., 2012).

The relationships between absolute fecundity $(F)$ and biometric variables of $N$. hexagonolepis were determined by simple linear regression after $\log _{10}$ transformation of the lengths ( $T L, S L$, and $F L$ ) and weights (TW and OW) data and the corresponding absolute fecundity estimates.

Size at first maturity: The size at first sexual maturity was estimated based on the $L_{50}$ Maturity scale (Size, at which $50 \%$ of the individuals have reached sexual maturity; Freitas et al., 2016). The samples, assigned to 
various maturity classes, were binarized as immature and mature. The samples with gonads that showed vivid signs of maturity were classified as mature, otherwise immature. Then, regression analysis was performed by considering total Length $(T L, \mathrm{~cm})$ as the explanatory variable and the stage of gonads (immature: 0; mature: 1) as the response variable (binomial). The variables were then fitted to a logistic function with the form:

$Y=1 / 1+\exp ^{\wedge}-\left(A+B^{*} X\right)$ (Torrejon-Magallanes, 2018) Where $Y=$ the probability of an individual of being mature at a determinate $X$ length; $X=$ total Length $(T L, c m)$; $A$ (intercept) and $B$ (slope) are parameters estimated.

Finally, the $L_{50}$ was calculated as: $L_{50}=-A$ / B

Statistical analysis: Statistical analyses were performed using R 4.0.0 software. Breusch-Pagan test was used to test for heteroskedasticity in a linear re- gression model. The normality test of each group of data was conducted by visual assessment of histograms and q-q plots and further confirmed with the Shapiro-Wilk test. The relationships between absolute fecundity $(F)$ and biometric variables of the fish were determined by simple linear regression. All statistical analyses were considered significant, at $5 \%(p<0.05)$.

\section{RESULTS}

Absolute fecundity $(F)$ estimated for 18 matured female fishes, ranging in TW from $340 \mathrm{~g}$ to $1200 \mathrm{~g}$ and in TL from $30.2 \mathrm{~cm}$ to $46.2 \mathrm{~cm}$ showed that the mean value of $F$ was $8356.44 \pm 4612.59$ and ranged from 2398.6 for the fish with TL $33.2 \mathrm{~cm}$, TW $430 \mathrm{~g}$, and OW $3.58 \mathrm{~g}$ to 20160 for the fish with TL $46.2 \mathrm{~cm}$, TW $1100 \mathrm{~g}$, and $\mathrm{OW} 30 \mathrm{~g}$. The relative fecundity to weight ranged from $5.58 \mathrm{~g}$ body weight for the fish with TL of

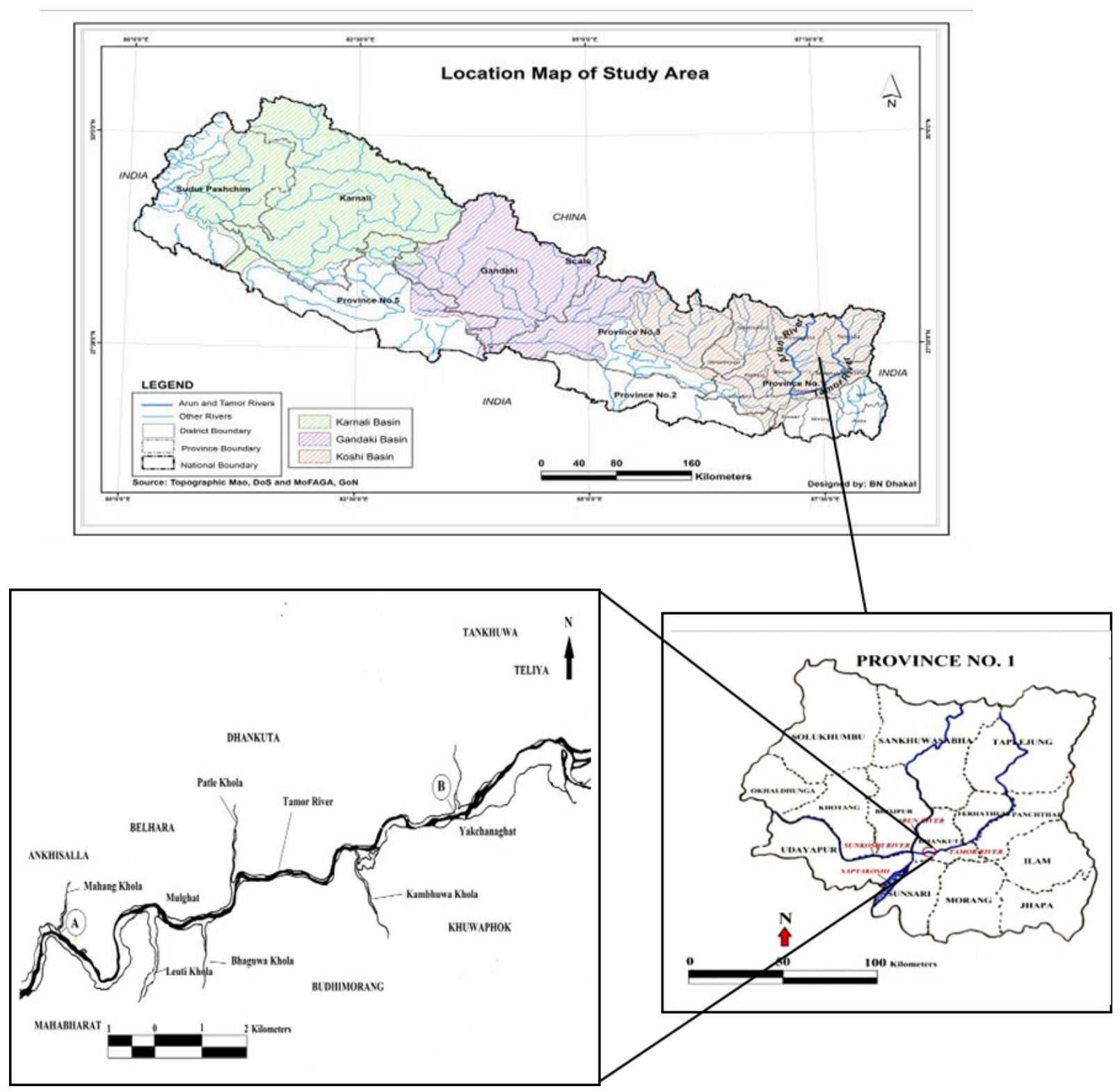

Fig. 1. Location of the study area for Neolissochilus hexagonolepis in Tamor River, Nepal. 

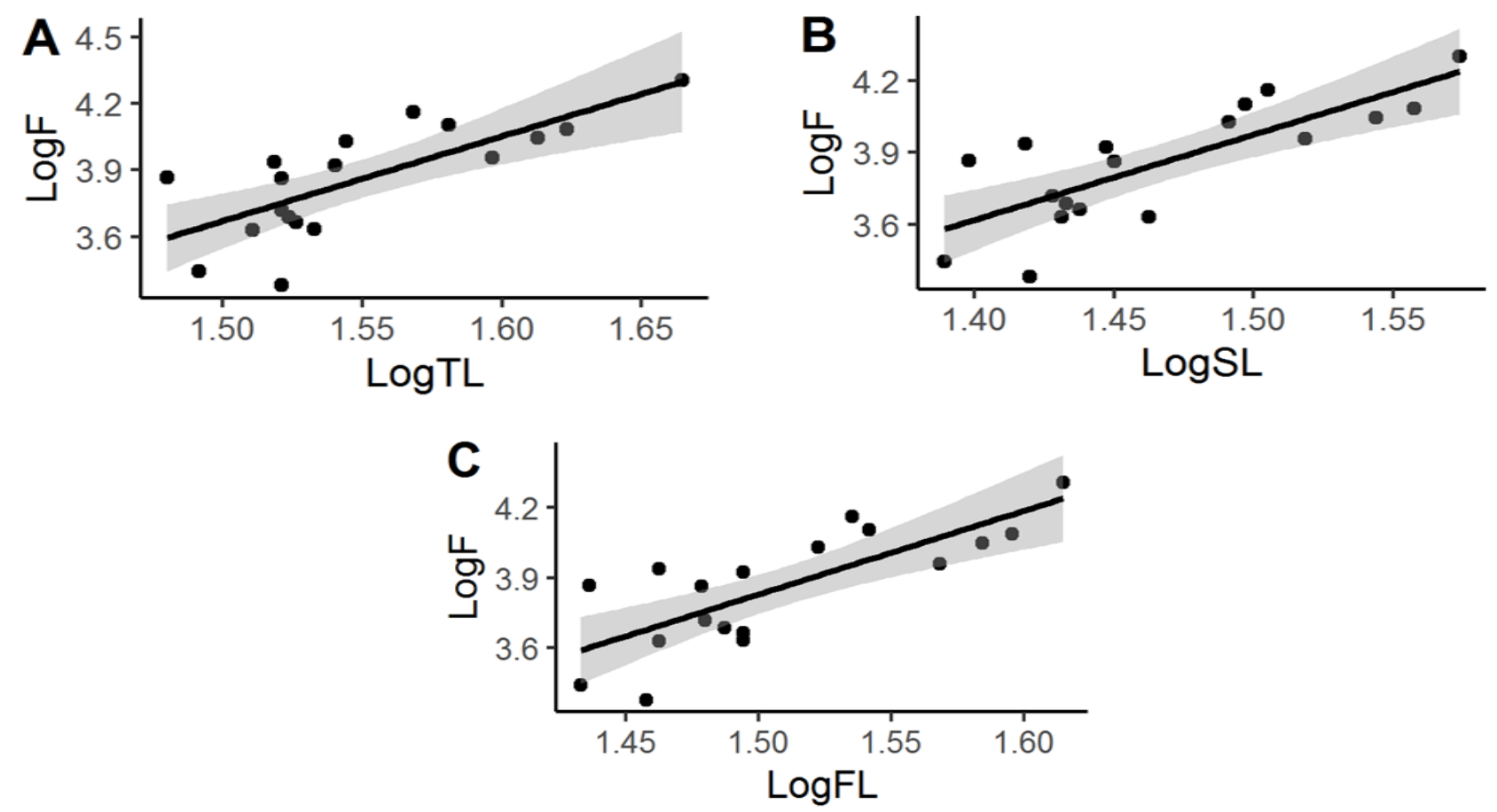

Fig. 2. Relationships between absolute fecundity (F) and lengths. (A) LogF vs. LogTL, (B) LogF vs. LogSL, and (C) LogF vs. LogFL of N. hexagonolepis from Tamor River, Nepal.
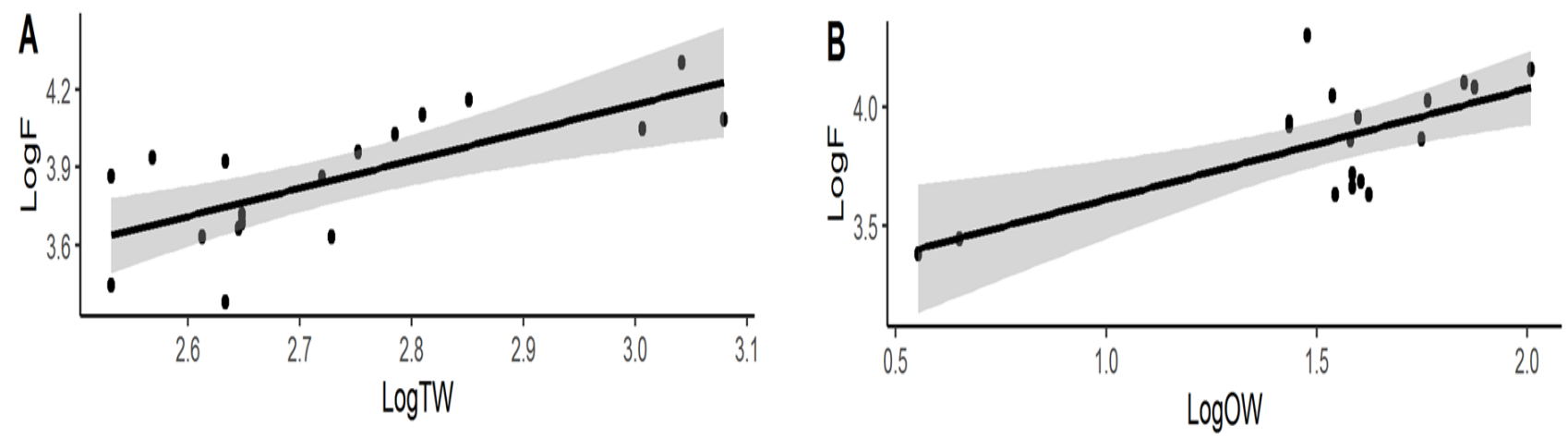

Fig. 3. Relationships between absolute fecundity (F) and weights. (A) LogF vs. LogTW, and (B) LogF vs. LogOW of N. hexagonolepis from Tamor River, Nepal.

$33.2 \mathrm{~cm}$ and TW $430 \mathrm{~g}$ to $23.38 \mathrm{~g}$ body weight for the fish with TL $33 \mathrm{~cm}$ and TW $370 \mathrm{~g}$. The relative fecundity to length ranged from $72.25 / \mathrm{cm}$ total length for the fish with TL of $33.2 \mathrm{~cm}$ and TW $430 \mathrm{~g}$ to $436.36 / \mathrm{cm}$ total length for the fish with TL of $46.2 \mathrm{~cm}$ and TW $1100 \mathrm{~g}$.

Relationships Between Fecundity and Biometric Variables: The relationships between absolute fecundity $(F)$ and biometric variables of $N$. hexagonolepis are shown in Fig. 2 and Fig. 3. The positive correlations between the variables were expressed by the following regression equations:

$\log \mathrm{F}=3.8265 \log T L-2.0691\left(n=18 ; R^{2}=0.5289 ;\right.$ $\mathrm{p}<0.001)$

$\log F=3.5733 \operatorname{LogSL}-1.3843\left(n=18 ; R^{2}=0.59364 ;\right.$ $\mathrm{p}<0.001)$

$\log F=3.5571 \log F L-1.5066\left(n=18 ; R^{2}=0.57083 ;\right.$ $\mathrm{p}<0.001)$

$\log F=1.0787 \log T W+0.90717\left(n=18 ; R^{2}=0.48555 ;\right.$ $\mathrm{p}<0.001)$

$\log F=0.46847 \operatorname{LogOW}+3.1426\left(n=18 ; R^{2}=0.44107 ;\right.$ $\mathrm{p}<0.01$

Histomorphology of ovaries: Based on the histomorphology, the ovaries of $N$. hexagonolepis were observed at six different stages viz. Stage I (Immature stage), Stage II (Maturing virgin), Stage III (Ripening), Stage IV (Mature), Stage V (Spawning), and stage VI (Spent) (Table 2, Plate I).

Maturation cycle of female gonad: Stage II ovaries occurred throughout the year with their frequency ranging from $7.69 \%$ in July to $57.14 \%$ in September. Next in frequency were the ovaries at stage I constituting $20 \%$ in February to $69.23 \%$ of the total monthly catch in January. Ovaries at the mature and spawning stages were en- 
Table 1. Descriptive statistics and estimated parameters of the absolute fecundity-length and absolute fecundity-weight relationships (sample size $=18$ ) of female $N$. hexagonolepis from Tamor River, Nepal $\left({ }^{*}\right.$, significant at $5 \%$ ).

\begin{tabular}{|c|c|c|c|c|c|c|}
\hline \multirow{2}{*}{ Equation } & \multicolumn{2}{|c|}{ Regression parameters } & \multirow{2}{*}{$95 \% \mathrm{CL}$ of a } & \multirow{2}{*}{$95 \% \mathrm{CL}$ of $\mathrm{b}$} & \multirow{2}{*}{$\mathrm{R}^{2}$} & \multirow{2}{*}{$\mathrm{p}$} \\
\hline & $a$ & $\mathrm{~b}$ & & & & \\
\hline \multicolumn{7}{|c|}{ Absolute fecundity-Length } \\
\hline$F=a \times T L^{b}$ & 0.008 & 3.826 & -4.874 to 0.735 & 2.017 to 5.636 & $0.5289^{*}$ & $<0.001$ \\
\hline$F=a \times S L^{b}$ & 0.041 & 3.573 & -3.572 to 0.803 & 2.083 to 5.064 & $0.5936^{*}$ & $<0.001$ \\
\hline $\mathrm{F}=\mathrm{a} \times \mathrm{FL}^{\mathrm{b}}$ & 0.031 & 3.557 & -3.848 to 0.835 & 2.005 to 5.109 & $0.5708^{*}$ & $<0.001$ \\
\hline \multicolumn{7}{|c|}{ Absolute fecundity-Weight } \\
\hline$F=a \times T W^{b}$ & 8.075 & 1.079 & -0.610 to 2.425 & 0.525 to 1.633 & $0.4855^{*}$ & $<0.001$ \\
\hline$F=a \times O W^{b}$ & 1388 & 0.469 & 2.733 to 3.552 & 0.207 to 0.730 & $0.4410^{*}$ & $<0.01$ \\
\hline
\end{tabular}

Abbreviations: F, Absolute fecundity; TL, Total Length; SL, Standard Length; FL, Forkal length; TW, Total weight; OW, Ovary weight; $a$, intercept; $b$, slope; $C L$, Confidence limit; $R^{2}$, Coefficient of determination; $p$, Probability value

Table 2. Morphological and histological description of gonad maturation stages of female N. hexagonolepis.

\begin{tabular}{|c|c|c|}
\hline Maturity stages & Morphology & Histological characteristics \\
\hline Stage I (Immature) & $\begin{array}{l}\text { Ovaries thin, slender, thread-like, dirty white } \\
\text { in color and translucent. }\end{array}$ & $\begin{array}{l}\text { Ovarian wall thick. Ovigerous lamellae with } \\
\text { nests of oogonia. Oocytes at stages I and II } \\
\text { visible. }\end{array}$ \\
\hline $\begin{array}{l}\text { Stage II (Maturing vir- } \\
\text { gin) }\end{array}$ & $\begin{array}{l}\text { Ovaries are still slender but slightly larger } \\
\text { than at stage I. Translucent white with less } \\
\text { vascular supply. }\end{array}$ & $\begin{array}{l}\text { Ovarian wall thick. Oocytes at stages III and } \\
\text { IV, along with a few oocytes at stages I and II } \\
\text { visible in ovigerous lamellae. }\end{array}$ \\
\hline Stage III (Ripening) & $\begin{array}{l}\text { Ovaries whitish-yellowish in color with a } \\
\text { granular appearance. Ovaries further in- } \\
\text { creased in weight and volume. }\end{array}$ & $\begin{array}{l}\text { Ovarian wall thin. Ovigerous lamellae filled } \\
\text { with a large number of oocytes at stages IV } \\
\text { and V along with a few oocytes at stage VI. }\end{array}$ \\
\hline Stage IV (Mature) & $\begin{array}{l}\text { Ovaries broad and deep yellowish occupy- } \\
\text { ing almost the entire abdominal cavity. } \\
\text { Ovarian wall skinny through which ripe yel- } \\
\text { lowish oocytes visible to naked eyes. Vas- } \\
\text { cularization conspicuous. }\end{array}$ & $\begin{array}{l}\text { The ovarian wall is fragile. A large number of } \\
\text { stage VII oocytes and some ripe eggs visible. }\end{array}$ \\
\hline Stage V (Spawning) & $\begin{array}{l}\text { Ovaries large and distended, occupying the } \\
\text { entire abdominal cavity. The ovarian wall is } \\
\text { thin and almost transparent-a large num- } \\
\text { ber of jelly-like yellowish translucent eggs } \\
\text { present in the ovaries. Eggs were present in } \\
\text { the oviduct also and the eggs expelled out } \\
\text { even on applying slight pressure. Spawning } \\
\text { was imminent. }\end{array}$ & $\begin{array}{l}\text { Stage VII oocytes and ripe eggs are seen in } \\
\text { the ovigerous lamellae with several dis- } \\
\text { charged follicles. }\end{array}$ \\
\hline Stage VI (Spent) & $\begin{array}{l}\text { Ovaries flaccid, shrunken to about } 1 / 2 \text { length } \\
\text { of the body cavity. Wall loosened, some } \\
\text { unspawned large ova, and a large number } \\
\text { of smaller yellow-whitish oocytes visible. } \\
\text { Less vascular supply. }\end{array}$ & $\begin{array}{l}\text { Oocytes at stage VII, along with oocytes at } \\
\text { stages I and II visible in the ovigerous lamel- } \\
\text { lae. Ovaries characterized by many degener- } \\
\text { ated and atretic follicles. }\end{array}$ \\
\hline
\end{tabular}

countered until November. Spent ovaries (stage VI) occurred in November and December. No spent ovaries were examined from January onward (Fig. 4).

Size at first maturity: For estimating the size at first sexual maturity ( $L_{50}$ Maturity scale) of female $N$. hexagonolepis, its ovaries were assigned to maturity classes (I to VI) based on their gross histomorphological criteria. And, on the $\mathrm{L}_{50}$ Maturity scale, the samples with gonads at III, IV, V, and VI were assigned as mature and I and II as immature. The relation between total Length ( $T L, \mathrm{~cm}$ ) and mature proportion was plotted on a logistic diagram for estimating the length at $50 \%$ maturity. The sexual maturity logistic curve for female $N$. hexagonolepis is shown in Fig. 5. The logistic model obtained from the Total Length (TL) and sexual maturity data indicated that $50 \%$ of females acquired sexual maturity at TL $32.9 \mathrm{~cm}$.

\section{DISCUSSION}

Information on the reproductive traits of hill-stream fishes is very inadequate from Nepalese rivers. Data pertaining to the reproductive biology of $N$. hexagonolepis, including its fecundity estimation, is still unavailable from this region. Elsewhere, various methods for estimation of fecundity have been adopted in fisheries science. However, the two most common 

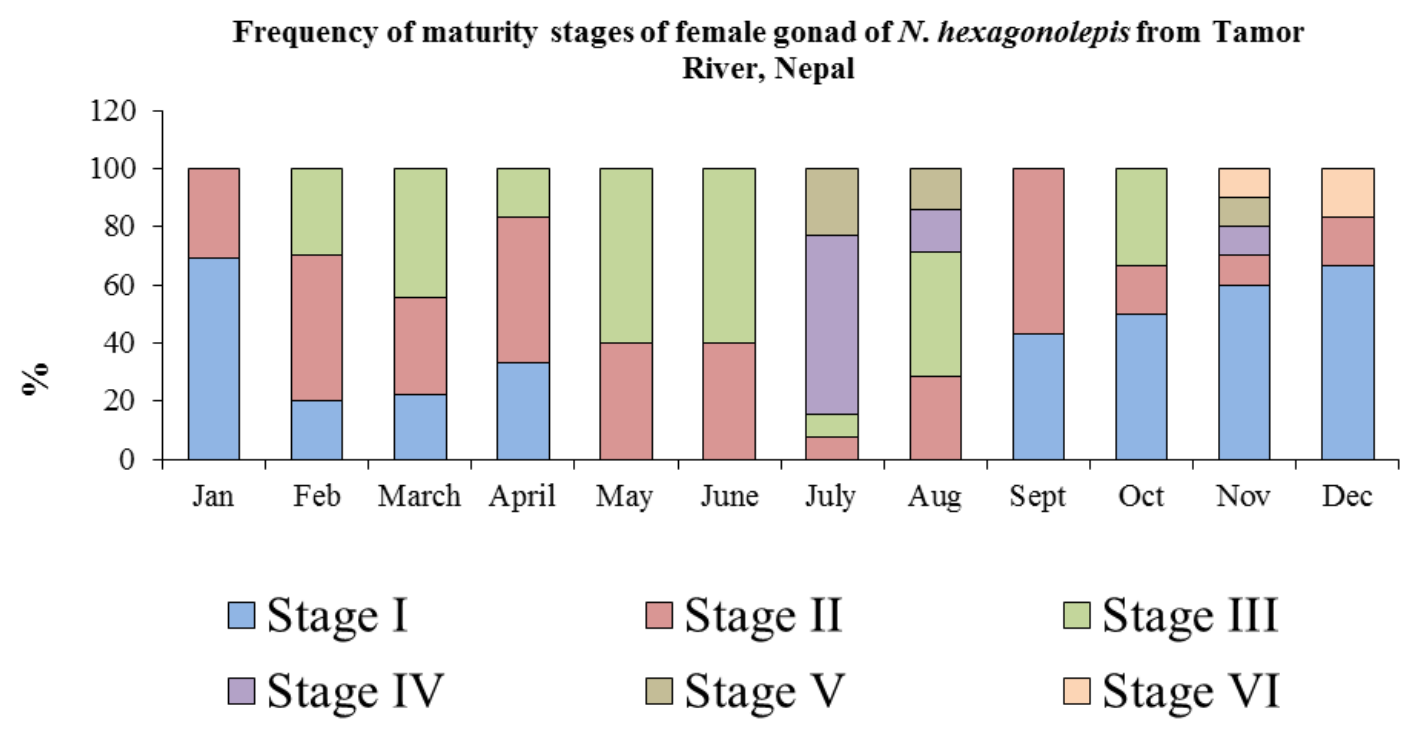

Fig. 4. Monthly change in frequency of maturity stages of the female gonad of N. hexagonolepisin Tamor River, Nepal.

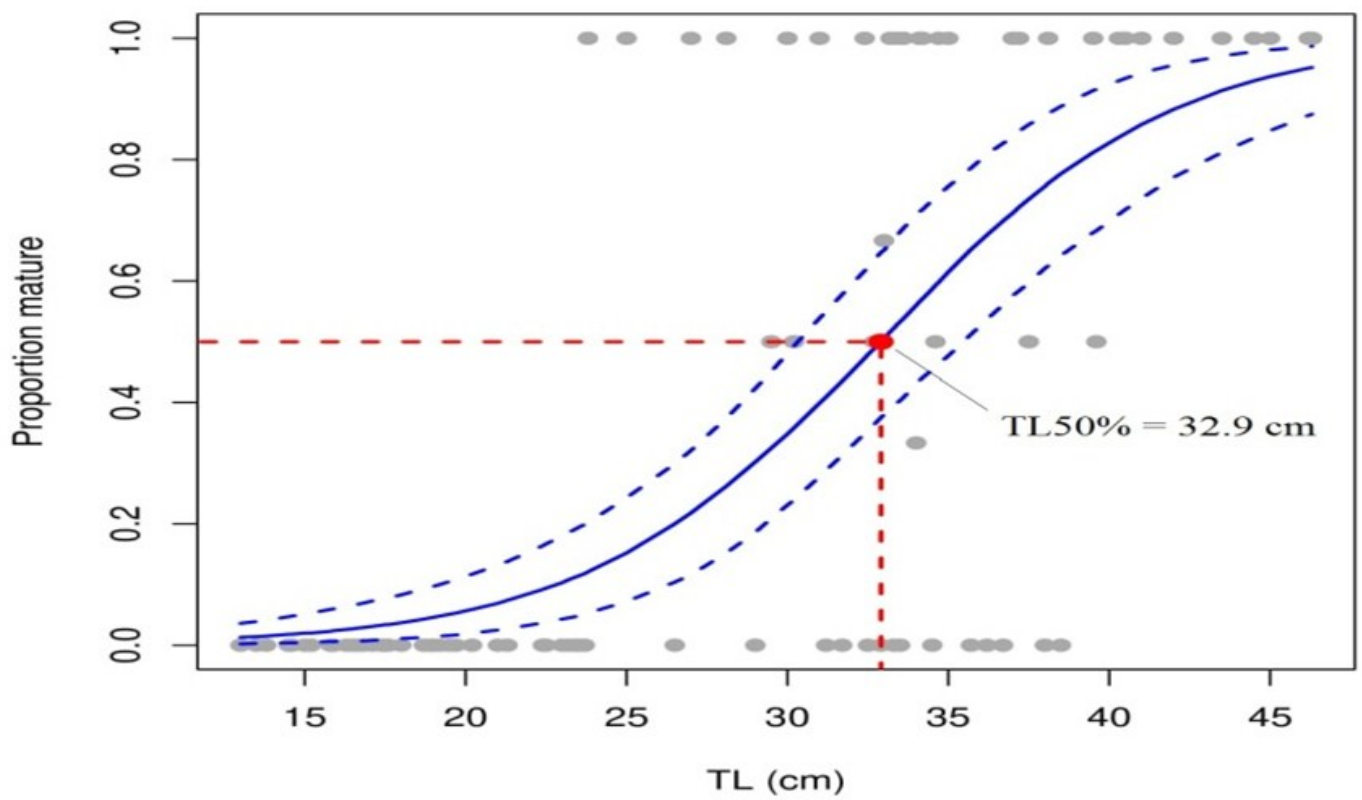

Fig. 5. Maturity ogive showing length at maturity of female N. hexagonolepis from Tamor River, Nepal.

methods still in practice are the volumetric and gravimetric methods. The first method involves counting a sub-sample of eggs based on volume (Simpson, 1951), while the latter method is based on the relation between ovary weight and oocyte density in the ovary (Bagenal and Braum, 1978). Perhaps the most rigorous way of estimating the number of eggs in ovaries is to count them all, by using egg-counting machines. However, as the number of eggs in the ovaries of fish is high, it is quite unrealistic to count them all manually. So, in the present study sub-sample method was adopted for the estimation of the fecundity of the candidate fish.

The low absolute fecundity estimated for $N$. hexagonolepis in the River Tamor was in full agreement with the finding of Dasgupta (1988). Despite low fertili- ty, N. hexagonolepis is a prolific breeder (Dasgupta, 1988). The fishes inhabiting cold water streams and lakes have comparatively low fecundity (Rasool and Ulfat, 2013).Fecundity of a fish is affected by environmental factors and food supplies (Simpson, 1951), and is determined by the cumulative effect of diet, age, disease, and atmospheric conditions of the environment in which the fish lives (Ulfat et al., 2014).According to Scott (1962), the fecundity of a fish depends upon the food intake, and poor nutrition intensifies the shrink in the number of eggs produced by the fish. Nikolsky (1963) also pointed out that the food consumed by a fish not only is associated with its fecundity but also affects the eggs' quality.

Several authors have reported on the fecundities of freshwater fishes. Alam and Pathak (2010), Agbugui 


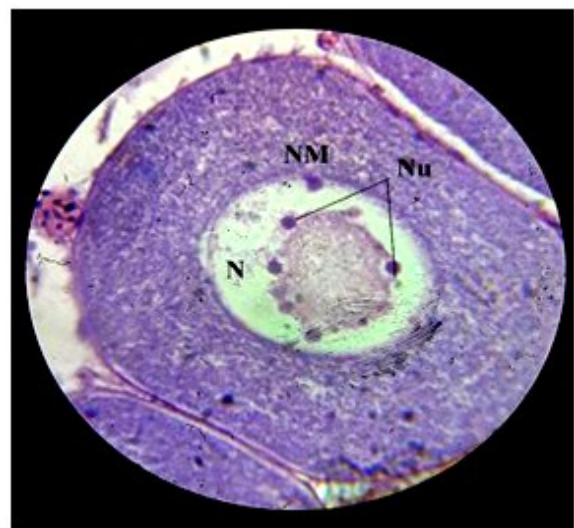

A

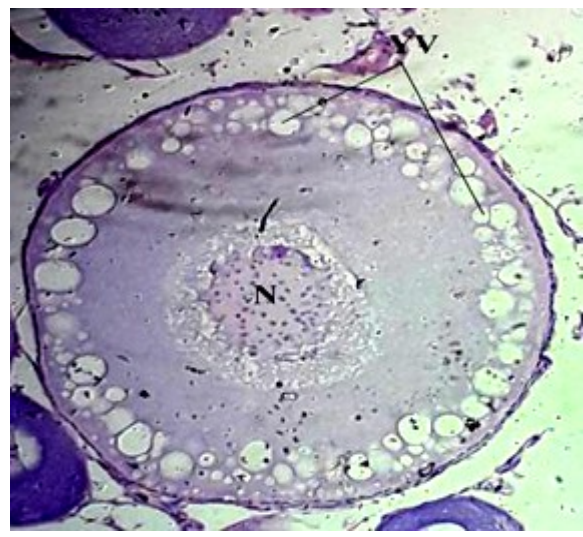

$\mathrm{D}$

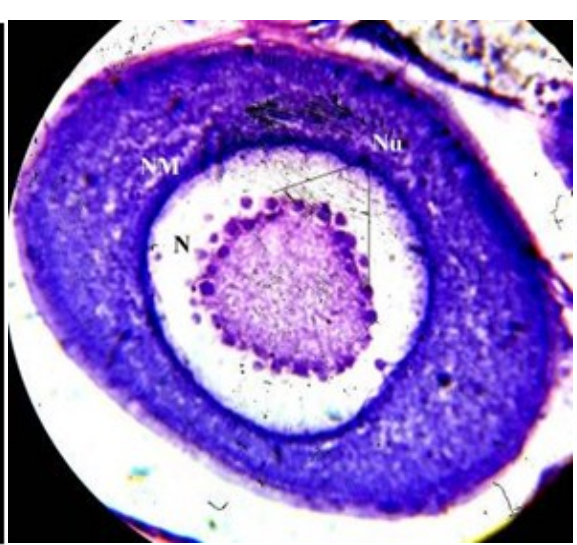

B

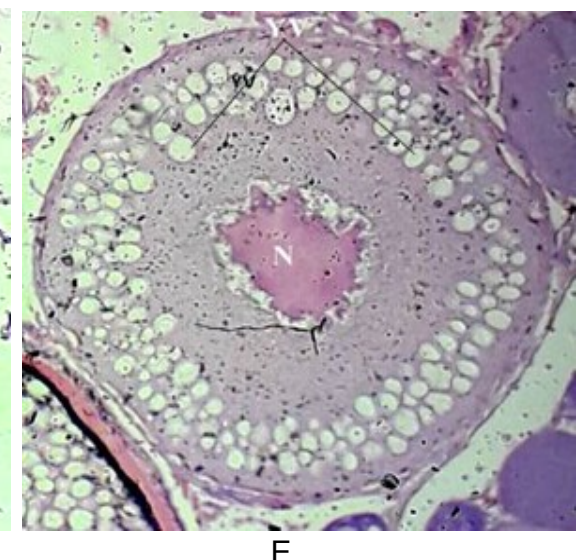

$\mathrm{E}$

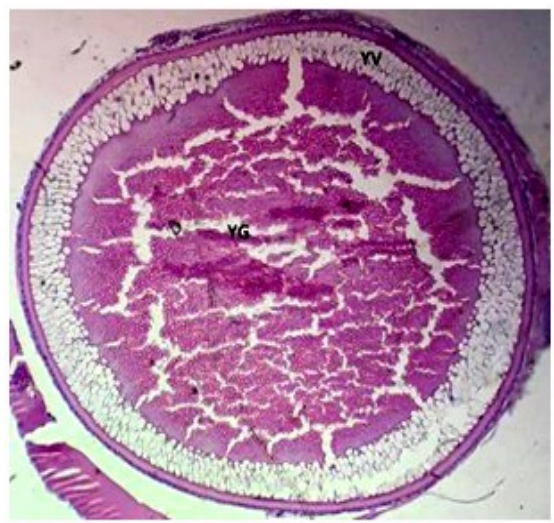

G

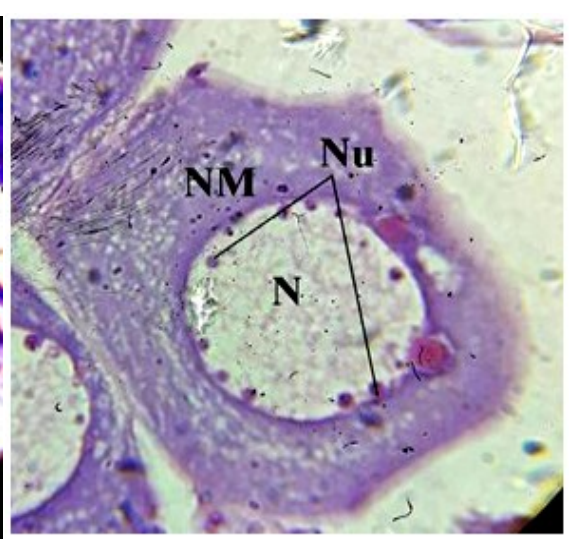

C

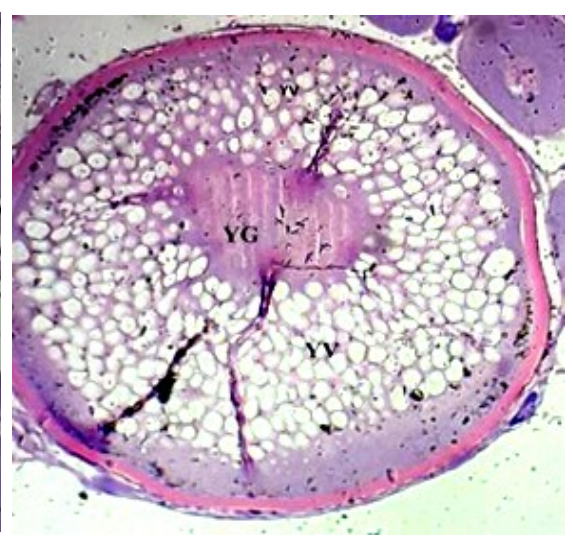

$\mathrm{F}$

Plate I. Various stages of oocytes of N. hexagonolepis in Tamor River, Nepal. A: Stage I oocyte with multiple nucleoli (Nu), Nuclear membrane (NM) and Nucleus (N) X 1000 (H and E) B: Stage Il oocyte (Early perinucleolus stage) with multiple nucleoli (Nu) adjacent to the nuclear membrane (NM) X 1000 (H and E) C: Stage Il oocyte (Late perinucleolus stage) with multiple nucleoli (Nu) adjacent to the nuclear membrane (NM) X 1000 (H and E) D: Stage III oocyte with yolk vesicles (YV) X 1000 ( $H$ and E) E: Stage IV oocyte with yolk vesicles (YV) and yolk globules (YG) X 1000 (H and E) F: Stage V oocyte with yolk vesicles (YV) X 1000 ( $H$ and E) G: Stage VI oocyte with yolk globules (YG) and yolk vesicles (YV) $X 1000$ ( $H$ and $E)$.

(2013), Arjamand et al. (2013), Khaironizam and Ismail (2013), Kharat and Khillare (2013), Wagle (2014), Bhattacharya and Banik (2015), Jabeen et al. (2016) and Jan and Ahmed (2016) reported on the fecundities of Pomadasys jubelini, Labeo rohita, Tor putitora, Neolissochilus soroides, Nemacheilus moreh, Schizothorax richardsonii, Ompok pabo, Barilius bendelisis, and Schizothorax plagiostomus respectively.

In the present study, the mean absolute fecundity of $N$. hexagonolepis was $8356.44 \pm 4612.59$ eggs per fish, and the average relative fecundity was estimated at $14.25 \pm 5.35$ eggs per gram body weight as opposed to 17.5 eggs per gram body weight by Mahapatra and Vinod (2011). The difference might be artificial (due to differences in the techniques used for the estimation of 
fecundity) or natural (owing to a difference in fecundity due to variations in environmental factors at different locations). Fecundity depends on the size of fish and that the availability of more visceral volume in larger fishes provides room for a larger number of eggs within the gonad (Shinkafi et al., 2011). Variation in fecundities among the fishes of equal length is common and results due to various environmental factors including temperature, availability of food, and also due to the difference in genetics (Kharrat and Khillare, 2013).

Relative fecundity decreases with an increase in body weight (Wagle, 2014), and that the variation in the fecundities among the fishes of the same as well as different species are affected by their size, age, condition, food intake and space (Jan and Ahmed, 2016).

The absolute fecundity of the fish was found to be positively correlated with $T L\left(R^{2}=0.53\right), S L\left(R^{2}=\right.$ 0.59), $F L\left(R^{2}=0.57\right)$, TW $\left(R^{2}=0.49\right)$ and $G W\left(R^{2}=\right.$ 0.44). Significant positive correlations between the absolute fecundity and lengths (TL, SL, and FL) indicated that the number of eggs in the ovaries of $N$. hexagonolepis increases with the increasing length of the fish. The significant positive associations between the absolute fecundity and the weight variables (TW and GW) indicated that the number of eggs in the ovaries of the candidate fish increases proportionately with its body and gonad weight. The finding of the present study corresponds well with earlier reports by Shinkafi et al. (2011) and Khaironizam and Ismail (2013) in Auchenoglanis occidentalis and Neolissochilus soroides, respectively. Positive linear relationships between fecundity and body parameters were also reported in Anabas testudineus (Marimuthu et al., 2009), Nemacheilus moreh (Kharrat and Killare, 2013), Tor putitora (Arjamand et al., 2013), Pomadasys jubelini (Agbugui, 2013), Neolissochilus soroides (Khaironizam and Ismail, 2013), Schizothorax niger and S. esocinus (Ulfat et al., 2014), Schizothorax richardsonii (Wagle, 2014), Ompok pabo (Bhattacharya and Banik, 2015), Barilius bendelisis (Jabeen et al., 2016) and S. plagiostomus (Jan and Ahmed, 2016).

The associations between absolute fecundity of the candidate fish with its body metrics hinted that the length parameters are better at predicting the total number of eggs within its body. This might be linked to the fractional spawning behaviour of the fish, which releases fractions of eggs over the protracted period.

Fecundity of $N$. hexagonolepis varied among the individuals of the same length and weight. Appetite and overall health condition of the fish seem to be the deciding factors in this regard. Analogous results were also reported by Marimuthu et al. (2009) and Bhattacharya and Banik (2015) in Anabas testudineus and Ompok pabo, respectively.
Fully matured and spawning fishes were captured from July till November, indicating that the breeding season of $N$. hexagonolepis has a protracted period. The protracted breeding period of $N$. hexagonolepis, also been reported by Jhingran (1982) and Jyrwa and Bhuyan (2017), could be considered as an adaptive feature of the species to combat environmental pressures in hillstreams like the high mortality of juveniles in monsoon flooding. Furthermore, availability of the spent females during November and December and none from January onwards plainly indicated that the spawning season of the fish lasts till late November or early December.

The size at first sexual maturity is defined as the length at which a randomly chosen sample has a $50 \%$ chance of being mature (Somerton, 1980). Earlier, the logistic curve for estimating the size at first sexual maturity has been successfully used for several species of fishes (Bandpei et al., 2011; Valdez-Pineda et al., 2014; Nandikeswari, 2016; Freitas et al., 2016; Peixoto et al., 2018). The logistic model for estimating the size at first sexual maturity by visual inspection of gonads $\left(\mathrm{L}_{50} \mathrm{Ma}-\right.$ turity scale) revealed that female individuals of $N$. hexagonolepis attained the first sexual maturity at TL 32.9 $\mathrm{cm}$. Shrestha (2008) suggested that female N. hexagonolepis attains the first maturity at $23 \mathrm{~cm}$. The deviation in size at first sexual maturity in female $N$. hexagonolepis might be due to the difference in the environmental factors at different locations. Freitas et al. (2016) reported different results with modifying approaches during the assessment of the minimum size at first maturity of female fish. Nikolsky (1969) suggested that most of the males reaching maturity at smaller and younger compared to females illustrate the longer duration of life of the female fishes that mature later. Helfman et al. (1997) also suggested that, in most teleosts, female individuals attain the first sexual maturity at larger sizes compared to males.

\section{Conclusion}

Neolissochilus hexagonolepis exhibited protracted breeding period with its ovaries passing through six different stages of maturation. Female individuals attained the first sexual maturity at total length $32.9 \mathrm{~cm}$. Absolute fecundity of the fish was found to be better anticipated by its length parameters. In conclusion, the present study has provided imperative clues on the length at first sexual maturity, fecundity, and maturation cycle for $N$. hexagonolepis that will be pragmatic in similar studies in the days to come. Further, the finding of the study may also serve as a protocol for fishery biologists and managers to promulgate adequate regulations for continual fishery management in the River Tamor, Nepal. 


\section{ACKNOWLEDGMENTS}

The authors are grateful to the local fishermen for the collection of the specimens of $N$. hexagonolepis from Tamor River during the study. This work was supported by the Central Department of Zoology, Tribhuvan University, Nepal.

\section{Conflict of interest}

There are no conflicts of interest for the publication of this manuscript.

\section{REFERENCES}

1. Agbugui, M.O. (2013). The sex ratio, gonado-somatic index, stages of gonadal development and fecundity of the Grunt Pomadasys jubelini (Cuvier, 1830) in the New Calabar-Bonny River. Report and Opinion, 5: 31-37.

2. Alam, M., and Pathak, J.K. (2010). Assessment of fecundity and gonado-somatic index of commercially important fish, Labeo rohita from Ramganga river. International Journal of Pharma and Bio Sciences, 1: 1-6.

3. Arjamand, S., Dar, S.A., Desai, A.Y., Sayani, A.N., Yusufzai, S.I., Ashfaq, M., Bhola, D.V., and Fofandi, M.D. (2013). Reproductive biology of an endangered coldwater fish Golden Mahseer, Tor Putitora (Ham.) from Anji Mahseer hatchery Reasi ( $\mathrm{J}$ and $\mathrm{K}$ ). IOSR Journal of Pharmacy, 3: 13-16.

4. Bagenal, T.B. (1957). Annual variations in fish fecundity. Journal of Marine Biological Association the United Kingdom, 36: 377-382.

5. Bagenal, T.B., and Braum, E. (1978). Eggs and early life history. In: Bagenal, T., Ed., Methods of Assessment of Fish Production in Freshwaters, IBP Handbook 3. Oxford, Blackwell Scientific.

6. Bandpei, A., Mashhor, M. A. M., Abdolmaleki, S. H., Najafpour, S. H., Bani, A., Pourgholam, R., ... \& Janbaz, A. A. (2011). The environmental effect on spawning time, length at maturity, and fecundity of kutum (Rutilus frisii kutum Kamensky, 1901) in Southern Part of Caspian Sea, Iran. Iranica Journal of Energy \& Environment, 2(4), 374381. DOI:10.5829/idosi.ijee.2011.02.04.3097

7. Bhattacharya, P., and Banik, S. (2015). Study of the fecundity of Ompok pabo (Hamilton, 1822), an endangered fish species of Tripura, India. J Fisheries Livest Prod, 3: 153. DOI:10.4172/2332-2608.1000153

8. Brown-Peterson, N.J., David, M.W., Fran, S.R., Beverly, J.M., and Susan, K.L.B. (2011). A standardized terminology for describing reproductive development in fishes. Marine and Coastal Fisheries: Dyanamics, Management, and Ecosystem Science, 3: 52-70. DOI: 10.1080/1942512 0.2011 .555724

9. Chondar, S.L. (1977). Fecundity and its role in racial studies of Gudusia chapra (Pisces: Clupeidae). Proc. Indian Acad. Sci., 86 245-254.

10.Dasgupta, S.M. (1988). A study on the fecundity of Acrossocheilus hexagonolepis (McClelland) from Garo hills, Meghalaya, Uttarpradesh. J. Zool., 8: 159-167.

11.Freitas, T.M.D., Almeida, V.H.D., Montag, L.F.D., and Fontoura, N.F. (2016). Predicting size at first sexual maturity from length/weight relationship: a case study with an
Amazonian catfish. Neotropical Ichthyology, 14: 177-183.

12.Helfman, G.S., Collette, B.B., and Facey, D.E. (1997). The diversity of fishes. Oxford, Blackwell Science, 544p.

13.Holden, M.J., and Raitt, D.F.S. (1974). Manual of fisheries science. Part 2: Methods of resource investigation and their application. FAO Fish. Tech. Rep. 115(Rev. 1), Rome, Italy.

14.Hossain, M. Y., Rahman, M. M., \& Abdallah, E.M. (2012). Relationships between body size, weight, condition, and fecundity of the threatened fish Puntius ticto (Hamilton, 1822) in the Ganges River, Northwestern Bangladesh. Sains Malaysiana, 41: 803-814.

15.IUCN 2018. The IUCN Red List of Threatened species. Version 2018-1.

16.Jabeen, F., Talukdar, B., Kalita, H.K., and Sarma, D. (2016). Fecundity of the lesser baril, Barilius bendelisis (Hamilton,1807) from Manas river, Assam, India. Poult Fish Wildl Sci, 4(2). DOI: 10.4172/2375-446X.1000172.

17.Jan, M., and Ahmed, I. (2016). Assessment of fecundity, gonado-somatic index, and hepatosomatic index of snow trout, Schizothorax plagiostomus in river Lidder, from Kashmir Himalaya, India. International Journal of Fisheries and Aquatic Studies, 4: 370-375.

18.Jhingran, V.G. (1982). Fish and fisheries of India. Hindustan Publishing Company, India.

19.Jyrwa, L.B., and Bhuyan, R.N. (2017). Histological studies of gonads in Neolissochilus hexagonolepis (McClelland,1839) (Teleostei: Cyprinidae) from Meghalaya, India. Iran. J. Ichthyol, 4: 140-149. DOI: 10.7508/iji.2017

20.Khaironizam, M.Z., and Ismail, M.Z. (2013). Spawning period and fecundity of Neolissocheilus soroides (Duncker,1904) (Pisces, Teleostei, Cyprinidae) from a small Malaysian stream. Turkish Journal of Zoology, 37: 65-72. DOI: 10.3906/zoo-1201-10

21.Kharat, S.S., and Khillare, Y.K. (2013). Gonado-somatic index, ova diameter, and fecundity of freshwater hill stream teleost Nemacheilus moreh (Sykes). International Journal of Bioassays, 2: 992-995.

22.Kjesbu, O.S., and Kryvi, H. (1989). Oogenesis in cod, Gadus morhua L., studies by light and electron microscopy. J.Fish Biol., 34: 735-746.

23.Mahapatra, B.K., and Vinod, K. (2011). Reproductive biology and artificial propagation of chocolate mahseer Neolissocheilus hexagonolepis (McClelland) in Meghalaya, India. Indian J. Fish, 58: 35-40.

24.Marimuthu, K., Arumugam, J., Sandragasan, D., and Jegathambigai, R. (2009). Studies on the fecundity of native fish climbing perch (Anabas testudineus, Bloch) in Malaysia. Am.-Eurasian J. Sustain. Agri., 3: 266-274.

25.Morales, D.A. (1991). La Tilapia en Mexico. Biologia, Cultivoy Pesquerias. A G Editor S.A., 190pp.

26.Murua, H., Kraus, G., Saborido-Rey, F., Witthames, P.R., Thorsen, A., and Junquera, S. (2003). Procedures to estimate fecundity of marine fish species in relation to their reproductive strategy. J. Northw.Atl.Fish.Sci., 33: 33-54.

27.Nandikeswari, R. (2016). Size at first maturity and maturity stages of Terapon puta (Cuvier, 1829) from Pondicherry coast, India. International Journal of Fisheries and Aquatic Studies, 4: 452-454.

28.Nikolsky, G.V. (1963). The Ecology of fishes. New York, London Academic Press. 
29.Parenti, L.R., and Grier, H.J. (2004). Evolution and phylogeny of gonad morphology in bony fishes. Integr Comp Biol, 44: 333-348.

30.Peixoto, S., Calazans, N., Silva, E. F., Nole, L., Soares, R., \& Frédou, F. L. (2018). Reproductive cycle and size at first sexual maturity of the white shrimp Penaeus schmitti (Burkenroad, 1936) in northeastern Brazil. Latin american journal of aquatic research, 46(1), 1-9.

31.Rasool, N., and Ulfat, J. (2013). Study on the fecundity of Salmo trutta fario (Brown trout) in Kashmir. Journal of Biology and Life Science, 4: 181-193.

32.Scott, D.P. (1962). Effect of food quantity on the fecundity of rainbow trout, Salmon gairdneri. Journal of the Fisheries Research Board of Canada, 19: 715-731.

33.Shinkafi, B.A., Ipinjolu, J.K., and Hassan, W.A. (2011). Gonad maturation stages of Auchenoglanis occidentalis (Valenciennes, 1840) in River Rima, North-Western Nigeria. Journal of Fisheries and Aquatic Science, 6: 236-246. DOI: $10.3923 /$ jfas.2011.236.246

34.Shrestha, J., Singh, D.M., and Saund, T.B. (2009). Fish diversity of Tamor River and its major tributaries of the eastern Himalayan region of Nepal. Nepal Journal of Science and Technology, 10: 219-223.

35.Shrestha, T.K. (2008). Ichthyology of Nepal: A Study of Fishes of the Himalayan Waters. Himalayan Ecosphere, Kathmandu, Nepal; 1-388 pp.

36.Simpson, A.C. (1951). The fecundity of the plaice. Fish
Invest., 17: 1-27.

37.Somerton, D. A. (1980). A computer technique for estimating the size of sexual maturity in crabs. Canadian Journal of Fisheries and Aquatic Sciences, 37: 1488-1494. DOI: 10.1139/f80-192.

38.Torrejon-Magallanes, J. (2018). sizeMat: Estimate Size at Sexual Maturity. R package version 1.0.0. (URL:https:// CRAN.R-project.org/package = sizeMat).

39.Ulfat, J., Shah, G.M., and Bhat, A.A. (2014). Relative and absolute fecundity of Schizothorax niger and Schizothorax esocinus at Dacchigam national park, Kashmir. Report and Opinion, 4: 43-46.

40.Valdez-Pineda, M.C., Morán-Angulo, R.E., Voltolina, D., and Castillo-Vargasmachuca, S. (2014). Population structure and reproductive aspects of puffer fish Sphoeroides annulatus (Jenyns, 1842) (Osteichthyes: Tetraodontidae), landed in Teacapán, Sinaloa, Mexico. Latin American journal of aquatic research, 42(1): 121-126.

41.Wagle, S.K. (2014). Studies on the gonado-somatic index, fecundity, and hatchability of domesticated stock of Asala Schizothorax richardsonii (Gray) from Nallu River of Lalitpur District. Our Nature, 12(1): 19-27. DOI: http:// dx.doi.org/ 10.3126/on.v12i1.12253

42. Yeldan, H., and Avsar, D. (2000). A preliminary study on the reproduction of the rabbitfish (Siganus rivulatus Forsskal, 1775) in the northeastern Mediterranean. Turkish Journal of Zoology, 24: 173-182. 